\title{
Notes on the PYgmy Killer Whale Feresa atTenuata Gray, 1874 (Cetacea: Delphinidae) in Venezuela, southeastern Caribbean
}

\author{
Luis A. Bermúdez-Villapol ${ }^{1}$, Alejandro J. Sayegh ${ }^{1}$, María A. Esteves ${ }^{2}$, \\ Maria S. Rangel ${ }^{2}$, Camila Rosso ${ }^{3}$ and Natalia I. Vera ${ }^{3}$
}

\begin{abstract}
Aвstract: The pygmy killer whale Feresa attenuata Gray, 1874 is one of the species usually known as "black fish", which is easily mistaken for the false killer whale, Pseudorca crassidens (Owen 1846) and the melon-head whale, Peponocephala electra (Gray, 1846), especially in the field. Prior to 2002, there were very few data on this species in Venezuela and the only reports were based on craneometric studies of stranded animals in the western region. Five new reports on this species have been recorded since in the northeastern zone of the country, based on sightings or assistance of live-stranded animals. Detailed comparisons were made on specimens observed in the field for their corrected identification. These sightings and strandings of $F$. attenuata are the first reported for the Venezuelan northeast basin, thus increasing the number of reports of pygmy killer whales to seven in the country and extending their known distribution through the southern Caribbean Sea.
\end{abstract}

Resumen: La orca pigmea Feresa attenuata (Gray, 1874) es una de la especies usualmente conocida como "peces-negros", las cual es fácilmente confundible con la falsa orca Pseudorca crassidens (Owen 1846) y la ballena cabeza de melón Peponocephala electra (Gray, 1846), especialmente en campo. Antes del año 2002, en Venezuela existía muy poca data sobre estas especies y los únicos reportes estaban basados en estudios cráneométricos de ejemplares varados en la región occidental del país. Cinco nuevos reportes han sido registrados en la región nororiental del país, basados en avistamientos o en atenciones de animales varados vivos. Detalladas comparaciones fueron realizadas sobre los especimenes observados en campo para una correcta identificación. Estos avistamientos y varamientos de F. attenuata son los primeros reportes de la cuenca nororiental de Venezuela, incrementándose a siete el numero de reportes de orca pigmea en el país y extendiéndose el conocimiento acerca de la distribución de la misma para el Caribe sur.

KeYwords: Pygmy killer whale, Feresa attenuata, Venezuela, southeastern Caribbean

\section{Introduction}

The pygmy killer whale Feresa atenuata is a poorly known species that inhabits tropical and subtropical waters of the world (Leatherwood et al., 1988). In the Caribbean, very few reports exist on sightings and strandings of this species, the latest including records for Puerto Rico (Rodriguez-Lopez and MignucciGiannoni, 1999), the British Virgin Islands (MignucciGiannoni et al., 2000), St. Vincent (Caldwell and Caldwell, 1971) and Dominica (Gricks, 1994). This species has been reported for Venezuela since 1977 and was included in the list of cetaceans of the country (Bolaños and Boher, 1997). Although F. attenuata was reportedly seen in Venezuelan waters for the first time by Romero et al. (1991), they subsequently questioned the validity of the record, due the difficulty in identification from sightings (Romero et al., 2001). Therefore, previous to this report, only two records of this species are effectively considered (Acevedo, 2001; Bolaños and Villarroel, 2003). The pygmy killer whale, part of a group of cetaceans known as "black fishes", is difficult to be correctly identified in the field since it tends to get easily confused with the false killer whale, Pseudorca crassidens (Owen, 1846) and with the melonheaded whale, Peponocephala electra (Gray, 1846) (Leatherwood and Reeves, 1983; Jefferson and Barros, 1997). As a result, many of the reports about this species are questionable and most of the confirmed reports available come from stranded animals (Mitchel, 1975).
The pygmy killer whale has a rounded head and no snout, with generally white lips, and in some cases the jaw can also present a white coloration (Leatherwood and Reeves, 1983). The dark layer in its dorsal region is one of the diagnostic features, as are the rounded ends of the pectoral flippers (Cawardine, 1995). They present an irregular white patch near the genital and anal regions, extending towards the flanks and occasionally towards the tail (Ross and Leatherwood, 1994). This study documents five new records, based on sightings and live strandings occurring during 2002-2004, which increases to seven the reports of the species for Venezuela, two of them for the western zone and five for the northeastern zone of the country.

\section{Sightings}

1. During 26 June, 10 July and 14 August 2003, field trips for cetacean sightings were carried out by researchers of the "Centro de Investigación de Cetáceos- CIC" (Cetacean Research Center), on board the vessel Concepción Mariño and Cacica Isabel belonging to the fleet of ferries of CONFERRY company. These were part of the project "Relative Frequency and Abundance of Cetaceans", surveying the area between Punta de Piedras in Nueva Esparta state $\left(10^{\circ} 53^{\prime} 53.88^{\prime \prime} \mathrm{N}, 64^{\circ} 06^{\prime} 20.94^{\prime \prime} \mathrm{W}\right)$ and Puerto La Cruz in Anzoategui state $\left(10^{\circ} 13^{\prime} 07.44^{\prime \prime} \mathrm{N}\right.$, $\left.64^{\circ} 38^{\prime} 37.8^{\prime \prime} \mathrm{W}\right)$. During these three voyages, pygmy killer whales were observed by three of the authors (SR, CR and NV), travelling close to the northern boundary of Mochima National Park.

\footnotetext{
${ }^{1}$ Centro de Investigación de Cetáceos CIC (Cetacean Research Center). E/S Los Robles, Isla de Margarita, 6313, Venezuela. E-mail: cicvenezuela@yahoo.com.

${ }^{2}$ Proyecto Delphinus, Isla de Margarita, 6010, Venezuela. E-mail: delphinus1711@hotmail.com.

${ }^{3}$ Universidad Jorge Tadeo Lozano. Carrera 4 \# 22-61, Bogotá, Colombia. E-mail: camilarosso@hotmail.com.
} 
The observations were carried out from the boat's gun deck, which offers excellent field of vision. Binoculars (Vivitar 7X35 and Tasco 7X50) were used to observe the identification features in detail. The following features were determined in all specimens: a) Clearly visible black coloration on the entire body except for a small fringe in the ventral zone and some white patches on the corner of the mouth and jaws, with reddish termination; b) Visible falcated and prominent dorsal fin, located in the middle dorsal region of the body observed during short and constant leaps; c) Body moderately robust towards the anterior third of the body and an approximate specimen size of $2.30 \mathrm{~m}$. In the first sighting, four specimens were observed travelling in a southwest direction, whereas in the second and third sightings only three specimens were observed, travelling in an easterly direction (Table 1). The first two events were observed in the same zone over the Cariaco basin, with depths exceeding 1350m. The last event was observed on the "Picua Grande" island formation, at Mochima National Park, with depths of about 100m (Figure 1). The external characteristics observed in the sighted animals allowed for their identification as pygmy killer whales and not false killer or melon-headed whales.

These sightings correspond to the first at-sea confirmed reports of the species in Venezuelan waters, and extend their distribution well into southern Caribbean Sea.

Table 1. Sightings of Feresa attenuata on the maritime route Punta de Piedras - Puerto La Cruz, Venezuela, during 2003.

\begin{tabular}{lcccccc}
\hline \hline DATE & TIME 24hrs & LAt./LONG. & $\begin{array}{c}\text { \# OF } \\
\text { ANIMALS }\end{array}$ & $\begin{array}{c}\text { DePTH } \\
(\mathrm{m})\end{array}$ & $\begin{array}{c}\text { DiRECTION } \\
\text { OF TRAVEL }\end{array}$ & ObSERVERS \\
\hline \hline 26 Jun. & $9: 41-9: 42$ & $10^{\circ} 29^{\prime} 08,64^{\prime \prime} \mathrm{N}-064^{\circ} 26^{\prime} 53,54^{\prime \prime} \mathrm{W}$ & 4 & 1263.73 & $\mathrm{NW}$ & Rangel, Rosso, Vera \\
10 Jul. & $9: 45-9: 50$ & $10^{\circ} 30^{\prime} 38,16^{\prime \prime} \mathrm{N}-064^{\circ} 26^{\prime} 23,46^{\prime \prime} \mathrm{W}$ & 3 & 1263.73 & $\mathrm{E}$ & Rangel, Rosso, Vera \\
14 Aug. & $10: 25-10: 27$ & $10^{\circ} 21^{\prime} 22,5^{\prime \prime} \mathrm{N}-064^{\circ} 31^{\prime} 32,34^{\prime \prime} \mathrm{W}$ & 3 & 117.21 & $\mathrm{E}$ & Rangel \\
\hline \hline
\end{tabular}

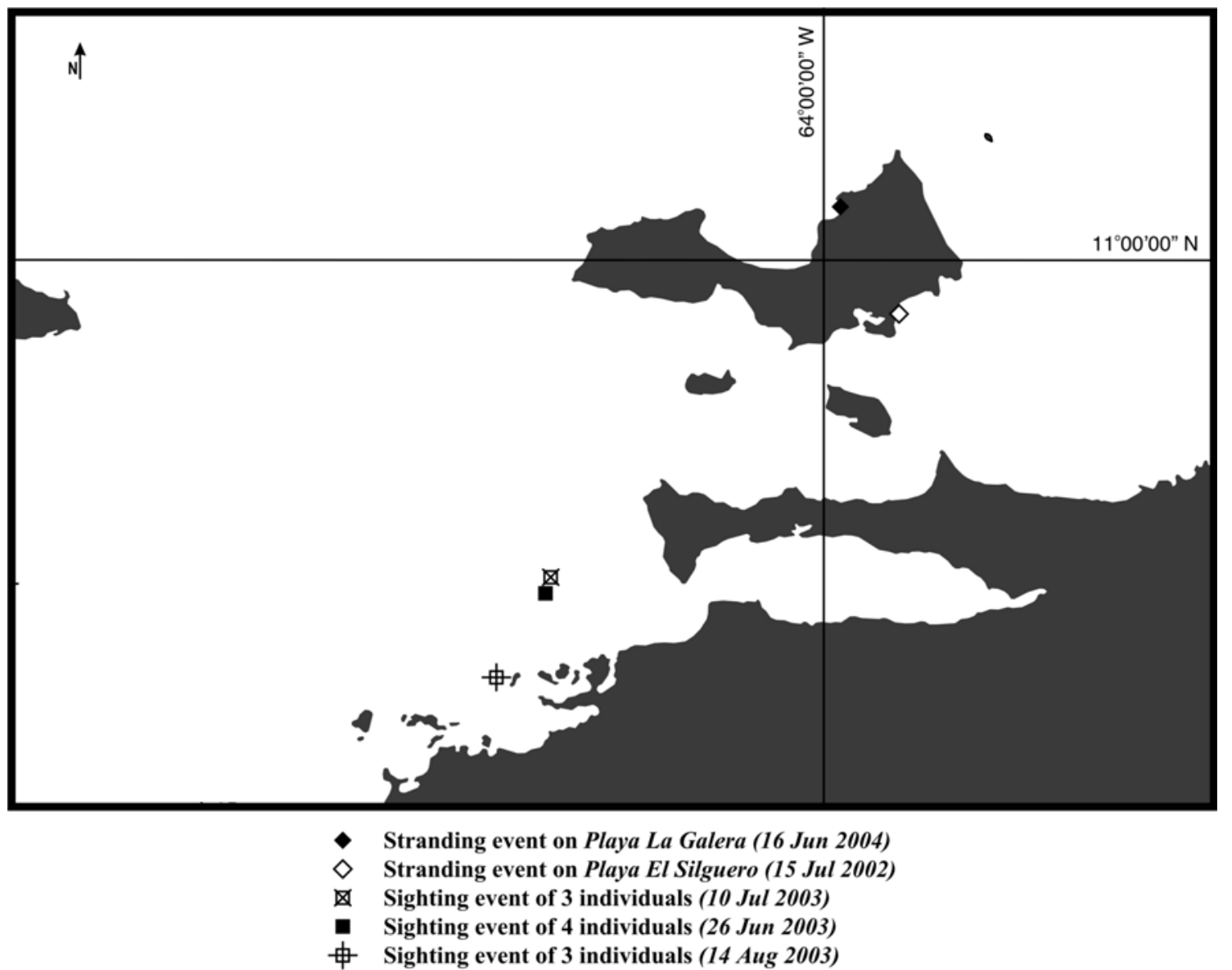

Figure 1. Location of Feresa attenuata strandings and sightings events for the Venezuelan northeast basin in the Period $2002-2004$. 


\section{Strandings}

1. The first report of F. attenuata in Venezuela is a skull deposited in the Museo de la Estación Biológica Rancho Grande, Dirección General de Diversidad Biológica del Ministerio del Ambiente y de los Recursos Naturales (EBRG-ONDB-MARN Museum) under accession number EBRG 22461, belonging to a $2.34 \mathrm{~m}$ adult female stranded in Sur Beach, Chichiriviche, Falcón state, Venezuela, in February 1997 (Villaroel et al., 2001).

2. The second report refers to a skull deposited in the same collection (number EBRG 22461). This skull comes from the single-species mass stranding of three live animals, on 17 February 1998, in Tucacas Beach, Falcón state, which was returned to the sea. However, apparently one of them, a $2.34 \mathrm{~m}$ female, was found dead near the latter (Bolaños and Villarroel, 2003).

3. A mass stranding of three juvenile males on 15 July 2002, on El Silguero Beach, in the southeast fringe of Margarita Island $\left(10^{\circ} 55^{\prime} 00^{\prime \prime} \mathrm{N}, 63^{\circ} 53^{\prime} 18^{\prime \prime} \mathrm{W}\right)$, in Nueva Esparta state, was assisted by the staff of the Centro de Investigación de Cetáceos (CIC), and other institutions (Figure 1). One of these whales was returned to the sea by local fishermen. However, it was found dead the following day near the original stranding location. A second specimen was found dead and a third one was taken in for rehabilitation; however, it died after five days of treatment in the facilities of the Escuela de Ciencias Aplicadas del Mar (School of Applied Sciences of the Ocean) in Universidad de Oriente (ECAM-UDO) (Figure 2). The three animals were subjected to a necropsy directed by the senior author (LB), together with veterinary and expert personnel of the Ministry of Environment of Venezuela (Bermudez et al., 20025). The first two animals were subjected to a gross necropsy on 16 July. Both animals showed hemorrhage and lung congestion, as well as the ectoparasite whale lice (Cyamidae) in the blowhole and eyelids. The first specimen showed mouth stomatitis, with ulcerations in the palate, bleeding, deformity and excessive dental wear. Four nematodes were found in the second stomach chamber, measuring about 4.5 to $5 \mathrm{~cm}$, possibly from the genus Anisakis, recorded in $F$. attenuata specimens from elsewhere (Mignucci-Giannoni et al., 2000; Aguilar-Aguilar et al., 2002). The second specimen showed normal appearance of all organs, with no parasites or mouth infections.

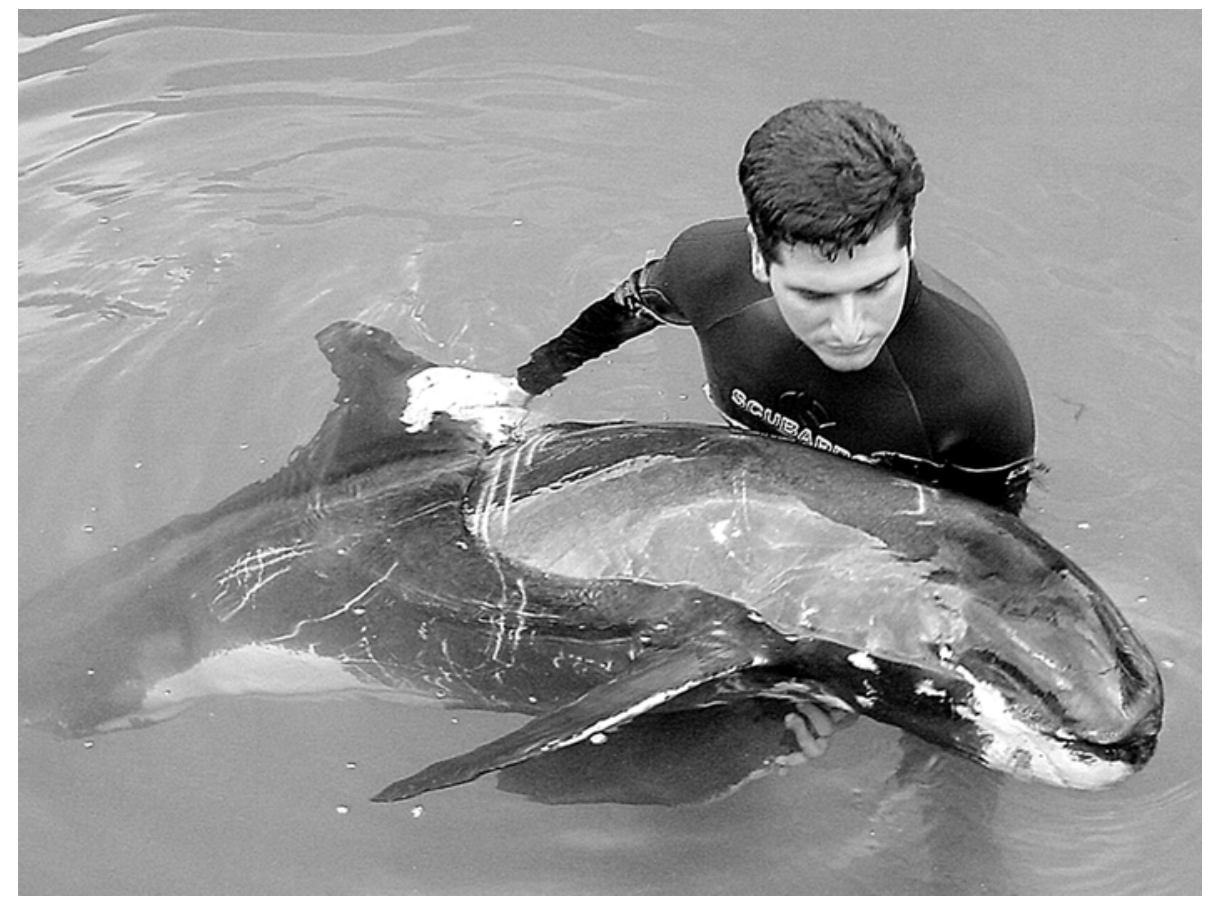

Figure 2. Specimen of Feresa attenuata stranded alive on El Silguero Beach (10 $55^{\prime} 00^{\prime \prime}$ N, 63 $53^{\circ} 18^{\prime \prime}$ W- 15 July 2002) and carried to ECAM-UDONE Facilities at Isla de Margarita - Venezuela, for rehabilitation.

\footnotetext{
${ }^{4}$ Villaroel, A., Bolaños, J., Ferrer, A., Narciso, S. (2001) On two Strandings of the Pygmy killer whale (Feresa attenuata Gray, 1874) in the central cosat of Venezuela: First Recordos for the Southern Caribbean Sea. Page. 225.In Abstracts XIV Biennial Conference on the Biology of Marine Mammals. 28 November -03 December Vancouver, British Columbia, Canada.

${ }^{5}$ Bermúdez, L., Sayegh, A., Esteves, M.A. and Cobarrubia, S. (2002) Primer reporte de varamiento de la especie Feresa attenuata (CETACEA:DELPHINIDAE) para las costas de la isla de Margarita, Edo. Nueva Esparta. Depositado en la Dirección Estadal Ambiental del Estado Nueva Esparta y en la Dirección Nacional de Diversidad Biológica MARN. 20 pp.
} 
The third animal died later on 19 July and showed one dental ectoparasite (Cirripedia, genus Conchoderma), on the right lower jaw, reported in cetaceans in the Caribbean (Rosario-Delestre et al., 1999), as well as cyamids in the eyelids. The rest of its organs were unremakable. The skull of this specimen showed lesions in its ventral aspect, consisting on basket-type formations, generated by a parasite of the genus Crassicauda, reported in other odontocetes (Montes et al., 2004).

4. On 16 June 2004, fishermen from La Galera Bay, north of Margarita Island $\left(11^{\circ} 04^{\prime} 55.2^{\prime \prime} \mathrm{N}, 63^{\circ} 58^{\prime} 26.4^{\prime \prime} \mathrm{W}\right)$, in Nueva Esparta state, returned to the sea a specimen stranded on the beach, which apparently had been swimming alone for more than two hours prior to stranding. After being returned to the sea, the animal was no longer seen by staff from the $C I C$, who surveyed the area in an attempt to track the animal. A detailed filming of the event performed by some tourists allowed the positive identification of the specimen by the first two authors (LB, AS) as a pygmy killer whale, representing the first report of this species for the north of Margarita Island (Bermudez-Villapol and Sayegh, 20056).

These stranding events on the western and northeastern areas of the country confirm the distribution of the pygmy killer whales in Venezuela waters and extend the range of the species for the southeastern Caribbean Sea.

These data contribute to what little is known about this species in the Caribbean. The seven records presented for Venezuelan waters represent nearly half of the published accounts for the region. With the exception of St. Vincent record, all others are located north of $15^{\circ} \mathrm{N}$, suggesting that pygmy killer whales may not be common in the southern Caribbean Sea. Though Caldwell and Caldwell (1971) point out that this species has been historically caught by fishermen in some areas of the Caribbean, this species has not been reported in areas close to the Venezuelan coasts or southern Caribbean waters, even if its presence can be expected, as in the case of the Colombian Caribbean (Cuervo-Díaz et al., 1986), the Leeward Ducth Antiles (Debrot et al., 1998) or Grenada (Romero et al., 2002).

\section{Acknowledgements}

We thank the CONFERRY company for its support to CIC's field research projects. Anonymous tourists provided the video footage that led to a positive identification of the specimen stranded in La Galera beach. ECAM-UDONE staff allowed the rehabilitation of the animal stranded in El Silguero Beach to be done in their facilities located in Boca de Río, Isla de
Margarita. We thank Jaime Bolaños for providing important literature for reference. Dr. Nélio Barros and two anonymous reviewers made helpful comments to this manuscript.

\section{References}

AcEvedo, R. (2001) Distribución y caracterización de habitats de los cetáceos marinos en las costas de Venezuela. BSc. Thesis. Universidad Central de Venezuela, Caracas, Venezuela, 242 pp.

Aguilar-Aguilar, R., Moreno-Naverrette, G. and DelgadoEstrella, A. (2002) Presencia de nemátodos del género Anisakis en una orca pigmea Feresa attenuata (Cetacea: Delphinidae) varada en costas de Veracruz, México. Anales del Instituto de Biología, Universidad Nacional Autónoma de México, Serie Zoología 732: $239-240$

Bolaños, J. AND BoHer, S. (1997) Lista actualizada de los cetáceos de Venezuela. Natura 104:51-53.

Bolaños, J. and Villarroel, A. (2003) Three new records of cetacean species for Venezuelan waters. Caribbean Journal of Sciencie 39: 230-232.

Caldwell, D.K. and Caldwell, M.C. (1971) The pygmy killer whale, Feresa attenuata, in the western Atlantic, with a summary of world records. Journal of Mammalogy 52:206-209.

Cawardine, M. (1995) Whales, Dolphins and Porpoises. A Dorling Kindersley Book. London, United Kingdom. 256 pp.

Cuervo-Díaz A., Hernández-Camacho, J. And Cadena, A. (1986) Lista actualizada de los mamíferos de Colombia. Anotaciones sobre su distribución. Caldasia 15(71-75):471-501

Debrot, A.O., De Meyer, J.A. And Dezenté P.J.E. (1998) Aditional records and review of the cetacean fauna of the Leeward Dutch Antilles. Caribbean Journal of Science 34: 204-210.

Jefrerson, T.A. And Barros, N.B. (1997) Peponocephala electra. Mammalian Species. American Society Mammalogists 553: 1-6

GRICKS, N. (1994) Whale-whacthing in the West Indies. St. Johns, Antigua, $40 \mathrm{pp}$

Leatherwood, S. and Reeves, R.R. (1983) The Sierra Club Handbook of Whales and Dolphins. Sierra Club Books, San Francisco, CA, USA. 302pp.

Leateherwood, S., Reeves, R.R., Perrin, W.F. and Evans, W.E. (1988) Whales, Dolphins and Porpoise of the Eastern North Pacific and Adjacent Artic Waters: a Field Guide to their Identification. Dover, NY, USA.

Mignucci-Giannoni, A.A., Toyos-González, G.M., PerezPadilla, J., Rodríguez-Lopez, M.A. And Overling, J. (1999) Mass stranding of pygmy killer whale (Feresa attenuata) in The British Islands. Journal of the Marine Biological Association of the United Kingdon 80: 756-760.

Mitchell, E.D. (1975) Report of the meeting on smaller cetaceans, Montreal, April 1-11, 1974. Journal of the Fisheries Research Board of Canada 32: 889-983.

\footnotetext{
${ }^{6}$ Bermúdez-Villapol, L. A. and Sayegh, A. J. (2005) Informe Técnico de Varamientos de Cetáceos en el Edo. Nueva Esparta, Venezuela, Período 2000-2004. Informe Técnico No. CICVAR2005-1. Depositado en la Dirección Estadal Ambiental del Estado Nueva Esparta y en la Dirección Nacional de Diversidad Biológica MARN. 69 pp.
} 
Montes, D., Chavera, A., van Bressem, M., Perales, R., Flacón, N. AND VAN WAEREBEeK, K. (2004) Descripción y evaluación anatómica de lesiones óseas cráneo-mandibulares en cetáceos odontocetos del mar peruano. Revista de Investigaciones Veterinarias del Perú 15:13-24.

Rodríguez-Lopez, M. A. and Mignucci-Gianoni, A.A. (1999) A stranded pygmy killer whale (Feresa attenuata) in Puerto Rico. Aquatics Mammals 25.2:119-121.

Romero, A., Hayford, K.T., Romero, A. ANd Romero, J. (2002) The marine mammals of Grenada, W.I., and their conservation status. Mammalia 66: 479-494

Rosario-Delestre, R., Rodríguez-López, M., Mignucci-Giannoni, A. And Mead, J.G. (1999) New records of beaked whales (Mesoplodonspp.) for the Caribbean. Caribbean Journal of Science 35: 144-148.

Ross, J.B. And Leatherwood, S. (1994) Pygmy Killer Whale Feresa atttenuata Gray, 1874. Pages 387-403. in RiDWAY, S.H. AND HARrISON, R. (Eds). Handbook of Marine Mammals. Volume 5: the First Book of dolphins. Academic press, London, United Kingdom. 416 pp. 